Kumawula, Vol. 1, No.1, April 2018, Hal 31 - 49 DOI:http://10.24198/kumawula.v1i1.19258

ISSN 2620-844X (online)

Tersedia online di http://jurnal.unpad.ac.id/kumawula/index

\title{
PEMAHAMAN USAHA MIKRO, KECIL DAN MENENGAH (UMKM) DI JATINANGOR TERHADAP KEWAJIBAN SERTIFIKASI HALAL PADA PRODUK MAKANAN
}

\author{
THE UNDERSTANDING OF USAHA MIKRO, KECIL DAN MENENGAH \\ (UMKM) IN JATINANGOR ON THE OBLIGATION OF HALAL \\ CERTIFICATION ON FOOD PRODUCTS
}

\author{
Akim $^{1}$, Neneng Konety ${ }^{2}$, Chandra Purnama ${ }^{3}$ Monita Hizma Adilla ${ }^{4}$ \\ 1, 2, ${ }^{3}$ Departemen Hubungan Internasional Universitas Padjadjaran \\ ${ }^{4}$ Alumni Hubungan Internasional Universitas Padjadjaran \\ *akim@unpad.ac.id
}

\begin{abstract}
As an education area, Jatinangor has been encountering a high rate of population and economic improvements which have encourage the development of Usaha Mikro, Kecil dan Menengah (UMKM) in Jatinangor. On the other side, the government implement the Undang-Undang No.33/2014 Jaminan Produk Halal that in 2019 all products have the halal-certified. In order for this policy run properly, it needs understanding from producers to provide halal products and register halal certification to guarantee consumer rights and satisfaction. The purpose of this study is to know the understanding of UMKM in Jatinangor in guaranteeing halal food products made by the possession of halal certificates issued by the authorized halal certification institution. The research method used is quantitative research methods with data collection techniques through questionnaires, observation, and semistructured interviews. The results of this study indicate that the understanding of UMKM in Jatinangor on halal certification is still relatively low. The market share of food products in Jatinangor has not been matched by the availability of food that is halal guaranteed through ownership of halal certification by UMKM as a food provider in Jatinangor. This condition is caused by a variety of reasons, but the main reason is the lack of knowledge, information, and socialization of the halal certification process itself as well as the problems in terms of costs that must be incurred to carry out the halal certification registration process.
\end{abstract}

Keywords: halal certification; usaha mikro, kecil dan menengah (UMKM); halal food products

\begin{abstract}
ABSTRAK
Sebagai kawasan pendidikan, Jatinangor telah mengalami pertumbuhan populasi dan perkembangan ekonomi yang mendorong perningkatan jumlah Usaha Mikro, Kecil dan Menengah (UMKM) di Jatinangor. Disisi lain, pemerintah menerapkan Undang-Undang no.33 tahun 2014 Jaminan Produk Halal di 2019 semua produk yang bersertifikat halal. Agar kebijakan ini berjalan dengan baik, dibutuhkan pemahaman dari produsen untuk menyediakan produk-produk halal dan mendaftarkan sertifikasi halal untuk menjamin hak konsumen dan kepuasan. Tujuan dari penelitian ini adalah untuk mengetahui pemahaman UMKM di Jatinangor dalam menjamin produk-produk makanan halal yang dibuat oleh kepemilikan sertifikat halal yang dikeluarkan oleh lembaga sertifikasi halal yang berwenang. Metode penelitian yang digunakan adalah metode penelitian kuantitatif dengan teknik pengumpulan
\end{abstract}


data melalui kuesioner, pengamatan dan wawancara semi-terstruktur. Hasil studi ini menunjukkan bahwa pemahaman UMKM di Jatinangor pada sertifikasi halal masih relatif rendah. Pangsa pasar produk makanan di Jatinangor tidak cocok oleh ketersediaan makanan yang halal dijamin melalui kepemilikan sertifikasi halal oleh UMKM sebagai penyedia makanan di Jatinangor. Kondisi ini disebabkan oleh berbagai alasan, tetapi alasan utama adalah kurangnya pengetahuan, informasi, dan Sosialisasi proses sertifikasi halal itu sendiri serta masalah-masalah dalam hal biaya yang harus dikeluarkan untuk melaksanakan sertifikasi halal proses pendaftaran.

Kata kunci: sertifikasi halal; usaha mikro, kecil dan menengah; makanan halal

\section{PENDAHULUAN}

Jatinangor merupakan salah satu kecamatan di Sumedang, Jawa Barat, yang menunjukkan perkembangan yang sangat dinamis baik dari segi kependudukan, pertumbuhan ekonomi dan pendidikan dibandingkan dengan kecamatan-kecamatan lain di Kabupaten Sumedang. Dari segi jumlah penduduk, data kependudukan tahun 2017 menggambarkan bahwa Jatinangor merupakan kecamatan dengan jumlah penduduk terbanyak dan terpadat pertama di Kabupaten Sumedang dengan 113.913 jiwa dan kepadatan 4.338 penduduk $/ \mathrm{km}^{2}$ (BPS Kabupaten Sumedang, 2018). Sementara dari aspek ekonomi, laju pertumbuhan ekonomi Kecamatan Jatinangor pada tahun 2016 berada di posisi tertinggi kedua setelah Sumedang Selatan yaitu mencapai 6,68 persen. Selain itu, Jatinangor juga menjadi kecamatan di Kabupaten Sumedang yang Produk Domestik Regional Bruto (PDRB) kecamatan yang paling tinggi dengan rata-rata pendapatan yang diterima oleh setiap penduduk selama satu tahun yaitu 35,41 juta (Dinas Komunikasi dan Informatika Persandian dan Statistik Kabupaten Sumedang, 2017). Dari aspek pendidikan, Jatinangor juga menjadi lokasi dari tiga perguruan tinggi dan satu sekolah kedinasan yaitu Universitas Padjadjaran (Unpad), Ikopin, Institut Teknologi Bandung (ITB) dan Institut Pemerintahan Dalam Negeri (IPDN).

Dinamisnya perkembangan ekonomi, kependudukan dan pendidikan di Jatinangor turut mempengaruhi peningkatan permintaan terhadap kebutuhan produk makanan di Jatinangor. Hal tersebut kemudian direspons oleh para pelaku usaha dengan menjamurnya berbagai usaha makanan dan minuman di Jatinangor baik usaha mikro, kecil maupun menengah (UMKM) dengan menyediakan berbagai kebutuhan pokok ataupun primer sehari-hari. Disisi lain, adanya fakta bahwa mayoritas masyarakat Jatinangor atau sekitar 98,8\% adalah muslim dan selebihnya 1,2\% penduduk yang non muslim (BPS Kabupaten Sumedang, 2018). Sehingga, memerlukan produk makanan yang sesuai dengan ketentuan syariat ajaran agama Islam. Bagi umat Islam, syarat utama makanan yang harus dipenuhi adalah kriteria halal. Halal adalah sebuah aturan prinsip dalam agama Islam yang digunakan untuk menyatakan bahwa sesuatu hal diijinkan atau 
dilarang untuk dikonsumsi oleh seorang muslim sesuai dengan apa yang tertulis dalam $\mathrm{Al}$ quran, hadist, atau ijtihad para ulama (Salehudin, 2010). Kehalalan suatu produk makanan tidak hanya bergantung kepada kehalalan bahan utama yang dipergunakan untuk membuat produk tersebut tetapi juga memperhatikan bahan-bahan campuran lainnya yang ada sejak awal produksi hingga ke tangan konsumen. Oleh karenanya, penting bagi para pelaku usaha makanan ataupun minuman memberikan kejelasan status halal atau tidaknya sebuah produk yang dijualnya. Dalam menjamin dan memberikan kepastian terhadap kehalalan suatu produk tersebut diperlukan suatu proses pemeriksaan komprehensif yang dilakukan oleh lembaga terpercaya yang dikenal dengan istilah Sertifikasi Halal.

Sertifikasi Halal adalah suatu proses untuk memperoleh sertifikat halal melalui beberapa tahap pemeriksaan untuk membuktikan bahwa bahan, proses produksi, dan sistem jaminan halal memenuhi standar Lembaga Pengkajian Pangan Obat-obatan dan Kosmetika Majelis Ulama Indonesia (LPPOM MUI). Adapun tujuan sertifikasi halal yaitu untuk memberikan kepastian status kehalalan suatu produk sebagai bentuk pemenuhan hak konsumen. Keyakinan konsumen terhadap kehalalan suatu produk akan mempengaruhi jumlah pembelian konsumen terhadap produk tersebut. Pada masa sebelumnya, pengajuan sertifikasi halal oleh produsen masih bersifat sukarela (voluntary). Akan tetapi, pasca pemberlakuan Undang-Undang Republik Indonesia Nomor 33 Tahun 2014 tentang Jaminan Produk Halal, pengajuan sertifikasi halal oleh produsen bersifat wajib (mandatory). Ketentuan tentang wajibnya sertifikasi halal bagi semua produk tersebut tertuang dalam pasal 4 yang menyatakan bahwa: "Produk yang masuk, beredar, dan diperdagangkan di wilayah Indonesia wajib bersertifikat halal” (Undang-Undang No. 33 Tahun 2014, 2014). Masih merujuk pada UU di atas, pemberlakuan kewajiban sertifikasi halal bagi semua produk di Indonesia akan berlaku pada 5 tahun ke depan sejak UU tersebut ditetapkan. Artinya tahun 2019 merupakan tahun pelaksanaan UU tersebut sehingga semua produk, termasuk produk makanan harus bersertifikasi halal (Abdullah, 2017).

Sertifikasi halal bermanfaat untuk menghilangkan keraguan konsumen terhadap kehalalan produk makanan tersebut. Isu keraguan konsumen terhadap kehalalan produk makanan pernah terjadi di Jatinangor. Misalnya isu penggunaan ayam tiren (mati kemaren), isu tersebut cepat menyebar dikalangan konsumen dan dampaknya sangat merugikan produsen karena akan mengurangi bahkan mematikan penjualan. Dilain pihak, produsen sulit untuk menepis isu tersebut mengingat produsen tidak memiliki bukti sertifikasi halal yang dikeluarkan oleh MUI. Berdasarkan data awal diketahui bahwa mayoritas UMKM di Jatinangor 
belum memiliki sertifikat halal terhadap produk makanan yang mereka jual. Maka dari itu, sosialisasi dan pengarahan sertifikasi halal kepada pelaku usaha makanan maupun minuman di Jatinangor menjadi suatu kegiatan yang dianggap penting untuk dilakukan. Selain itu, ketentuan pemerintah sesuai Undang Undang No.33 tahun 2014 yang mensyaratkan pada tahun 2019 seluruh produk yang dijual di masyarakat wajib memiliki sertifikat halal atau mendapat label halal mengindikasikan perlunya sebuah kajian lebih lanjut mengenai pemahaman sertifikasi halal produk makanan pada UMKM di Jatinangor sebagai bentuk perlindungan terhadap konsumen dan implementasi UU Jaminan Produk Halal.

Penelitian tentang sertifikasi halal telah banyak dilakukan sebelumnya oleh para peneliti dari berbagai bidang keilmuan. Purnomo (2011) menemukan bahwa Malaysia, Thailand dan Singapura lebih bersifat ekspansif dan ofensif dalam pengembangan pasar ekspor produkproduk negara-negara tersebut ke luar negeri, sementara Indonesia cenderung bersifat defensif. Penelitian tersebut menyarankan agar produk Industri Rumah Tangga (IRT) yang telah mendapat sertifikasi halal dari MUI mampu menembus dan bersaing di pasar terbuka. Keterkaitannya dengan penelitian ini adalah bahwa pentingnya sertifikasi halal bagi para pelaku bisnis dapat mendorong tingkat kepercayaan konsumen dan meningkatkan kualitas produk. Dengan demikian, disarankan bahwa setiap pelaku bisnis pangan baik itu industri besar ataupun rumahan untuk memiliki sertifikasi halal atas produknya. Hal tersebut sejalan dengan penjelasan Purnama (2015) tentang pentingnya pemahaman sertifikasi halal oleh UMKM, khususnya UMKM yang bergerak dalam bisnis olahan makanan. Adapun alasannya yaitu sebagai berikut: i) pelaku UMKM memiliki fungsi strategis secara sosial ekonomi dan sosial politik bagi rakyat Indonesia, ii) sertifikasi halal mampu menjamin produk UMKM berkualitas baik, iii) kualitas tersebut memberikan peluang bagi UMKM untuk go internasional dengan brand produk makanannya. Namun dalam prakteknya di Indonesia, walaupun Indonesia merupakan negara muslim pemahaman masyarakat Indonesia terhadap pentingnya makanan halal dan sertifikasi halal masih tergolong rendah. Permasalahannya terletak pada anggapan masyarakat yang menilai karena muslim adalah mayoritas, sehingga semua produk yang diperdagangkan oleh orang muslim adalah halal tanpa memastikannya lebih dalam. Sehingga para produsen menilai tidak perlu adanya sertifikasi halal untuk menarik kepercayaan masyarakat. Seperti yang di jelaskan Huda (2012) menggambarkan bahwa regulasi halal yang diwujudkan dengan sertifikasi halal dari Majelis Ulama Indonesia (MUI) belum sepenuhnya dipahami oleh para produsen makanan. 
Perbedaan penelitian ini dengan penelitian sebelumnya yaitu terkait dengan fokus dan lokus penelitian. Berbeda dengan penelitian lainnya di atas, fokus penelitian ini pada sertifikasi halal UMKM yang bergerak dalam produk makanan. Selain itu, perbedaan selanjutnya antara penelitian ini dengan penelitian-penelitian sebelumnya terkait dengan masalah lokus kajian. Penelitian ini memiliki lokus kajian di Jatinangor sebagai kawasan pendidikan di Sumedang Jawa Barat. Selanjutnya tujuan dari penelitian ini adalah untuk mengetahui pemahaman tentang sertifikasi halal dikalangan UMKM di Jatinangor dalam menjalankan usahanya serta dampaknya terhadap penjualan produk mereka. Adapun yang menjadi rumusan masalah dalam riset ini adalah: "Bagaimana pemahaman para pelaku UMKM produk makanan di Jatinangor terhadap ketentuan dan proses sertifikasi halal di Indonesia saat ini?”

\section{METODE}

Artikel ini merupakan hasil kolaborasi dengan kegiatan Pengabdian Pada Masyarakat Dosen Integratif (PPMD Integratif) Universitas Padjadjaran yang dilaksanakan di wilayah Kecamatan Jatinangor pada Semester Genap 2017/2018 dengan judul “Sosialisasi Sertifikasi Halal Terhadap UMKM di Kecamatan Jatinangor”. Metode riset yang digunakan dalam penelitian ini adalah metode kuantitatif. Teknik pengumpulan data dilakukan dengan menyebarkan kuesioner, observasi, dan wawancara terhadap UMKM makanan yang tersebar di wilayah Jatinangor. Konsep pemahaman dijadikan sebagai salah satu variabel yang hendak diteliti. Dalam riset ini, kawasan Jatinangor dibatasi hanya sepanjang jalan raya utama depan kampus mulai dari Jatinangor sebelah timur (Rumah Makan Suharti) depan Unpad sebagai batasan awal sampai dengan batas sebelah barat (Kedai Eat Boss) yang berada di wilayah GKPN, seberang IPDN Jatinangor. Pemilihan batas tersebut ditentukan berdasarkan wilayahwilayah persebaran utama UMKM makanan di Jatinangor. Populasi UMKM makanan yang tersebar di Jatinangor berjumlah 155 UMKM terdiri dari usaha mikro sebanyak 88 buah, usaha kecil sejumlah 45 buah dan usaha menengah sebanyak 22 buah. Dari total 155 UMKM makanan yang ada diperoleh jumlah sampel dengan menggunakan rumus Slovin yaitu sebanyak 112 UMKM. Komposisi dari UMKM ini sendiri terdiri dari 64 usaha mikro, 32 usaha kecil dan 16 usaha menengah.

Data yang digunakan adalah data cross-section. Penelitian ini menggunakan metode Simple Regression (SR) dengan tingkat signifikansi sebesar 5\%. Pengolahan data menggunakan Software Microsoft Excel 2010 dan Stata 12. Sistem skor digunakan untuk menjelaskan nilai dari masing-masing pertanyaan yang diajukan. Untuk jawaban ya=3, ragu-ragu=2, dan tidak=1. 
Sementara dalam pengolahan data dilakukan uji multikolinearitas, uji heteroskedastisitas, uji koefisien determinasi, uji parsial (uji t), dan uji simultan (uji f).

\section{HASIL DAN PEMBAHASAN}

Artikel ini merupakan luaran wajib yang harus dihasilkan dalam kegiatan pengabdian pada masyarakat yang dilakukan dosen yang pelaksanaannya terintegrasi dengan kegiatan kuliah kerja nyata mahasiswa. Pembiayaan kegiatan ini sepenuhnya dibiayai oleh Unpad melalui mekanisme Hibah Internal Unpad (HIU). Program ini terdiri dari dua kegiatan yang utama yaitu observasi lapangan dan kegiatan sosialisasi yang keduanya dilakukan secara bersama-sama oleh dosen dan mahasiswa.

\section{A. Observasi dan Pengenalan Sertifikasi Halal}

Kegiatan observasi dilakukan untuk mengetahui populasi dan wilayah penyebaran UMKM makanan yang tersebar di wilayah Jatinangor sehingga dapat ditentukan jumlah sampling dari UMKM makanan yang akan masuk dalam penelitian. Kegiatan observasi ini dilakukan dengan menyisir total jumlah UMKM makanan yang ada dari wilayah sebelah timur Jatinangor dimulai dari Rumah Makan Suharti sebagai batasan awal sampai dengan Kedai Eat Boss yang berada di wilayah GKPN, Jatinangor.

Observasi ini juga dilakukan dengan mengklasifikasikan UMKM ke dalam tiga kelompok usaha yaitu kecil, menengah, dan mikro. Pengelompokan UMKM makanan ini didasarkan pada besarnya pendapatan dan modal yang digunakan dalam usaha tersebut. Berdasarkan observasi tersebut diketahui bahwa jumlah UMKM makanan yang tersebar di Jatinangor berjumlah 155 UMKM dengan komposisi usaha mikro sebanyak 88 buah usaha, usaha makanan kategori kecil sejumlah 45 buah, dan usaha makanan kategori menengah sebanyak 22 buah.

Pada saat melakukan observasi juga dilakukan pengamatan terhadap tempat usaha maupun produk makanan yang dijual. Pengamatan terhadap tempat usaha dilakukan dengan cara mengamati apakah di tempat usaha tersebut seperti di dinding, jendela, papan nama tempat usaha, terdapat keterangan label halal. Pengamatan juga dilakukan pada produk makanan yang dijual, apakah dalam kemasan produk terdapat label atau logo halal dari lembaga yang berwenang dari lembaga yang berwenang yaitu LPPOM MUI. Sampai saat ini (2018), sebelum BPJPH beroperasi maka kewenangan untuk melakukan sertifikasi halal masih berada di tangan MUI. Sertifikasi Halal MUI adalah fatwa tertulis dari majelis ulama Indonesia yang menyatakan kehalalan dalam suatu produk sesuai dengan syari’at Islam (LPPOM MUI, 2008). 
Sertifikat halal MUI ini merupakan syarat untuk mendapatkan ijin pencantuman label halal pada kemasan produk dari instansi pemerintah yang berwenang. Tujuan dari sertifikasi halal MUI ini ialah untuk memberikan kepastian status kehalalan, sehingga dapat menentramkan batin konsumen pada saat konsumen tersebut mengkonsumsinya. Kesinambungan proses produksi halal dijamin oleh produsen dengan menerapkan Sistem Jaminan Halal.

Sertifikasi halal dalam UMKM di Indonesia terus mengalami peningkatan, hal ini sendiri terjadi karena adanya dorongan dari pemerintah agar setiap UMKM makanan di Indonesia memiliki label halal dalam produknya dan ditargetkan bisa tercapai pada tahun 2019. Hal ini dilakukan karena adanya kesempatan pasar halal yang dirasa terbuka besar bagi Indonesia dimana nilai dari produk pasar halal bisa mencapai 1,087 miliar dollar dan terus mengalami peningkatan. Saat ini, Indonesia menempati posisi negara konsumen terbesar dari produk makanan halal dunia yaitu sebesar USD 197 miliar USD dengan diikuti Turki mencapai USD 100 miliar (Nasar, 2017). Akan tetapi, anggapan Indonesia sebagai negara mayoritas muslim membuat masyarakat Indonesia terbiasa beranggapan bahwa makanan dan minuman yang diperjual belikan sudah pasti halal. Pemahaman masyarakat Indonesia akan perlunya sertifikasi halal di duga masih kurang dalam industri dan pasar halal dunia. Dengan demikian, Indonesia terus berupaya keras dalam menguatkan pemahaman tentang pentingnya sertifikasi halal pada produk baik pada masyarakat sebagai konsumen hingga para pelaku bisnis di dalam negeri, termasuk pada Usaha Mikro Kecil dan Menengah di kawasan Jatinangor.

\section{B. Sosialiasi Sertifikasi Halal Produk Makanan Terhadap UMKM di Jatinangor}

Kegiatan sosialisasi sertifikasi halal terhadap UMKM di Jatinangor dilakukan dengan cara mendatangi 112 UMKM makanan yang berada disepanjang Jalan Raya BandungSumedang, Jatinangor untuk mengenalkan memberikan pemahaman mengenai sertifikasi halal. Sosialisasi ini diawali dengan mengajukan beberapa pertanyaan terkait produk yang dijual serta menanyakan mengenai keyakinan para pelaku UMKM mengenai kehalalan dari produk yang dijual. Pertanyaan selanjutnya mengarah pada pemahaman pelaku UMKM terhadap proses sertifikasi halal dimulai dari menanyakan apakah responden sudah memiliki sertifikasi halal untuk produknya, menanyakan mengenai lembaga mana yang mengeluarkan sertifikasi halal, dan prosedural untuk mengajukan sertifikasi halal. Hal ini ditujukan untuk melihat pemahaman dasar pelaku UMKM terhadap sertifikasi halal, terutama dari segi kelembagaan dan administratif.

Selanjutnya ditanyakan kepada pelaku UMKM terkait tanggapan tentang relevansi antara sertifikasi halal dan produk makanan yang mereka jual. Pertanyaan dimulai dengan 
menanyakan keinginan responden untuk mendaftarkan produknya agar bisa memiliki label halal, kemudian dilanjut dengan menanyakan alasan mengapa produk yang mereka jual tidak memiliki label halal dan juga menanyakan apakah responden memiliki keinginan untuk mendaftarkan produknya untuk mendapatkan label halal tersebut. Kemudian ditanyakan pula mengenai sejauh mana tanggapan para usaha makanan di Jatinangor ini mengenai labelisasi produk mereka dan dampaknya terhadap penjualan produk mereka tersebut. Pertanyaan yang ditanyakan antara lain seperti menanyakan apakah sertifikasi halal akan memberikan dampak khusus bagi penjualannya, apakah sertifikasi halal memberikan keuntungan untuk meningkatkan minat beli konsumen serta apakah sertifikasi halal akan memberikan keuntungan lebih terhadap penjualan.

Tahapan berikutnya adalah kegiatan sosialisasi berupa pemaparan beberapa materi mengenai halal, produk halal, sertifikasi halal dan hubungan antara produk halal dengan omzet penjualan produk (Gambar 1). Terkait dengan konteks apa itu halal dan haram dalam makanan, dijelaskan bahwa agar bisa dikatakan halal dan sah secara syariat Islam, makanan yang diproduksi harus bebas dari unsur-unsur yang mengharamkan, seperti kandungan babi, alkholol, dan kandungan haram lainnya yang bisa saja terdapat dalam bahan-bahan lain seperti penyedap makanan, pewarna makanan dan yang lainnya. Selanjutnya juga dijelaskan bahwa halal dalam produk makanan juga bisa dipengaruhi dari penyedia bahan mentah seperti daging ayam, dan kehalalan dari produk bisa saja terancam jika daging ayam yang menjadi bahan utamanya tersebut merupakan ayam yang tidak disembelih sesuai dengan syariat Islam dan sehingga dapat memengaruhi kehalalan dari produk makanan yang dijual oleh UMKM tersebut.

Gambar 1

Penjelasan Mengenai Makanan Halal

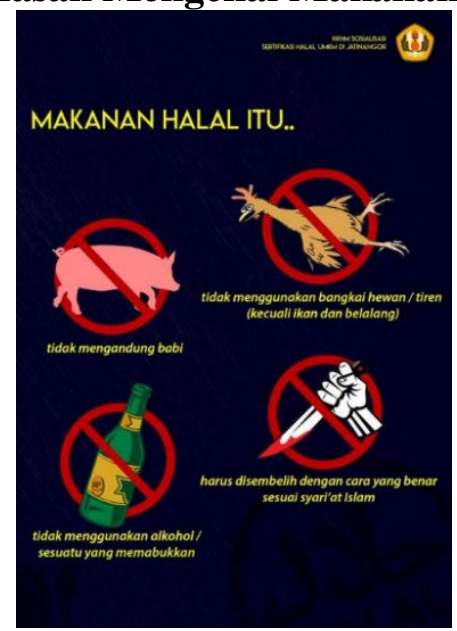

Sumber: Laporan KKNM-PPMD Integratif Unpad, 2018 
Kemudian dijelaskan juga mengenai tata cara atau prosedur yang harus ditempuh agar bisa mendapatkan sertifikasi halal (Gambar 2). Pertama adalah mengajukan permohonan oleh pemohon usaha, kemudian dilanjut dengan pemilihan LPH atau lembaga pemeriksa halal oleh pelaku usaha, kemudian dilakukan pemeriksaan dan pengujian kehalalan produk oleh LPH, kemudian dilaksanakannya penetapan kehalalan produk dan kemudian baru diterbikannya sertifikasi halal. Selain memberikan penjelasan secara lisan, kegiatan sosialisasi juga dilakukan dengan bantuan alat peraga berupa poster dan pamflet dengan tujuan agar penjelasan yang diberikan dapat lebih ilustratif sehingga mudah untuk dipahami para pelaku UMKM makanan Jatinangor (Akim dkk., 2018)

\section{Gambar 2}

Penjelasan Mengenai Alur Pengajuan Sertifikasi Halal

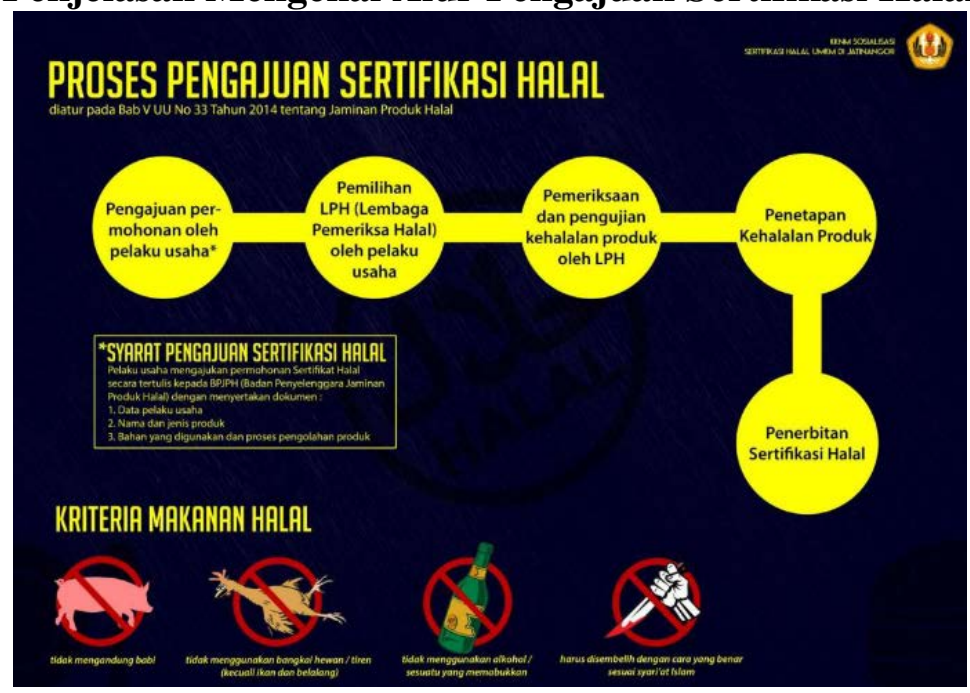

Sumber: Laporan KKNM-PPMD Integratif Unpad, 2018

Terakhir adalah pemaparan mengenai manfaat yang akan dimiliki oleh pelaku UMKM ketika produknya mendapatkan sertifikasi halal. Beberapa keuntungan yang akan didapat oleh para pengusaha UMKM tersebut antara lain meningkatnya kepercayaan konsumen terhadap produk yang dijual produsen, meningkatkan daya saing produk dengan produk sejenis di pasar karena sudah adanya label halal dalam produk, dan tentunya bisa semakin meningkatkan minat beli dari masyarakat yang beragama Islam dikarenakan sudah adanya jaminan akan kehalalan produk yang dijual tersebut dari lembaga yang berwenang sehingga tidak ada lagi rasa raguragu dari para pembeli yang akan membeli produk tersebut.

\section{Analisis Situasi}

Usaha mikro, kecil, dan menengah (UMKM) merupakan salah satu penopang utama perekonomian nasional sehingga memiliki posisi yang sangat penting dalam membangun 
kesejahteraan masyarakat. Hadirnya UMKM di tengah-tengah masyarakat dapat memperluas lapangan kerja dan memberikan penghasilan kepada masyarakat luas. Maraknya UMKM yang membuka usaha dibidang makanan dan minuman dari yang berbentuk kaki lima sampai restauran mencerminkan beragamnya jenis usaha makanan yang ada di masyarakat. Namun sangat disayangkan ketika masyarakat sebagai konsumen justru kurang peduli terhadap halal atau tidaknya (haram) makanan yang mereka konsumsi. Begitu juga dengan pelaku UMKM atau para pengusaha tempat makan yang cenderung kurang acuh terhadap makanan yang mereka produksi. Banyak pengusaha makanan yang berasumsi bahwa makanan yang diproduksi sudah menggunakan komposisi dan bahan-bahan yang aman bagi kesehatan sehingga tidak perlu untuk melakukan sertifikasi halal. Padahal, faktanya tidaklah demikian, penggunaan bahan makanan yang aman belum tentu secara otomatis menjadikan produk makanan tersebut menjadi halal, apalagi jika dalam proses produksi dan distribusi produk tersebut tidak memperhatikan aspek kehalalan.

Di Kecamatan Jatinangor sendiri jumlah UMKM dapat dikatakan berjumlah tidak sedikit. Baik itu UMKM yang masih berbentuk kaki lima sampai UMKM berbentuk restauran. Bentuk usaha dagang makanan dan minuman ini sebenarnya menjadi sumber mata pencarian bagi warga lokal Jatinangor. UMKM yang ada di Kecamatan Jatinangor pada dasarnya sudah tidak asing lagi dengan konsep sertifikasi halal. Hal ini dikarenakan bahwa pelaku UMKM di Jatinangor umumnya beragama Islam. Jatinangor yang merupakan wilayah pendidikan dengan mayoritas mahasiswanya beragama Islam tentu menjadikan aspek halal dari produk makanan yang dikonsumsi sebagai salah satu faktor yang penting. Sayangnya hal ini belum diiringi dengan pemahaman yang tinggi dari pelaku UMKM mengenai pentingnya sertifikasi halal itu sendiri. Kebanyakan pelaku UMKM yakin bahwa makanan dan minuman yang mereka jual merupakan produk halal dengan alasan bahwa mereka seorang muslim dan menggunakan bahan yang mereka anggap sudah dikategorikan makanan halal.

Selain itu, alasan lain pelaku UMKM kategori mikro di Jatinangor tidak memiliki sertifikasi halal yaitu karena adanya anggapan bahwa untuk mendapatkan sertifikasi halal itu memerlukan biaya yang cukup besar dan kurangnya pengetahuan tentang prosedur untuk mendapatkan sertifikasi halal. Bagi UMKM mikro upaya sosialisasi dan pendataan dari pemerintah sekitar mengenai sertifikasi halal ini sangat dibutuhkan, mengingat besarnya keinginan dari UMKM mikro ini untuk mengetahui atau mendapatkan sertifikasi halal. Sedangkan bagi kebanyakan UMKM kecil dan menengah yang sudah memiliki pemasukan cukup besar dan merupakan UMKM berbentuk franchise, kebutuhan untuk memperoleh 
sertifikat halal sudah diurus oleh pusat. Meskipun demikian, masih ada UMKM kecil dan menengah menganggap bahwa sertifikasi itu tidak terlalu penting karena mereka meyakini bahwa penyuplai bahan yang mereka olah sudah dapat dikategorikan sebagai makanan halal dan mereka mengolah makanan tersebut sudah sesuai dengan syariat Islam.

Pada penelitian ini, kuesioner disebarkan kepada 112 UMKM dengan komposisi UMKM terdiri dari 64 usaha mikro, 32 usaha kecil, dan 16 usaha menengah. Data yang diperoleh disajikan pada Tabel 1.

Tabel 1

Pemahaman Sertifikasi Halal UMKM Produk Makanan di Jatinangor

\begin{tabular}{|c|c|c|c|c|}
\hline No. & Keterangan & Usaha Mikro & Usaha Kecil & Usaha Menengah \\
\hline & $\begin{array}{l}\text { A. Urgensi produk makanan } \\
\text { halal }\end{array}$ & & & \\
\hline 1. & $\begin{array}{l}\text { Pedagang UMKM memeluk } \\
\text { agama Islam }\end{array}$ & $\begin{array}{l}\text { Dari } 64 \text { responden, } \\
\text { ada } 2 \% \text { responden } \\
\text { yang tidak } \\
\text { beragama Islam, } \\
\text { sisanya } 98 \% \\
\text { beragama Islam }\end{array}$ & $\begin{array}{l}\text { Dari } 32 \text { responden, } \\
\text { semua responden } \\
\text { bergama Islam }\end{array}$ & $\begin{array}{l}\text { Dari } 16 \text { responden, } \\
\text { Semua responden } \\
\text { beragama Islam }\end{array}$ \\
\hline 2. & $\begin{array}{l}\text { Semua produk makanan yang } \\
\text { dikonsumsi orang Islam harus } \\
\text { halal }\end{array}$ & $\begin{array}{l}\text { Dari } 64 \text { responden, } \\
\text { semua responden } \\
\text { setuju jika semua } \\
\text { produk makanan } \\
\text { yang dikonsumsi } \\
\text { orang Islam harus } \\
\text { halal }\end{array}$ & $\begin{array}{l}\text { Dari } 32 \text { responden, } \\
\text { semua responden } \\
\text { sepakat semua } \\
\text { produk makanan } \\
\text { yang dikonsumsi } \\
\text { orang Islam harus } \\
\text { halal }\end{array}$ & $\begin{array}{l}\text { Dari } 16 \text { responden, } \\
\text { semua responden } \\
\text { setuju semua } \\
\text { produk makanan } \\
\text { yang dikonsumsi } \\
\text { orang Islam harus } \\
\text { halal }\end{array}$ \\
\hline \multirow[t]{2}{*}{3.} & $\begin{array}{l}\text { Pedagang yakin bahwa produk } \\
\text { makanan yang dijualnya adalah } \\
\text { makanan/minuman halal }\end{array}$ & $\begin{array}{l}\text { Dari } 64 \text { responden, } \\
2 \% \text { responden } \\
\text { menjawab ragu- } \\
\text { ragu dan } 98 \% \\
\text { menyatakan yakin } \\
\text { produknya halal } \\
\end{array}$ & $\begin{array}{l}\text { Dari } 32 \text { responden, } \\
\text { semua responden } \\
\text { merasa yakin bahwa } \\
\text { produknya halal }\end{array}$ & $\begin{array}{l}\text { Dari } 16 \text { responden, } \\
\text { semua responden } \\
\text { merasa yakin } \\
\text { bahwa produknya } \\
\text { halal }\end{array}$ \\
\hline & $\begin{array}{l}\text { B. Pemahaman tentang cara } \\
\text { produksi makanan halal }\end{array}$ & & & \\
\hline 4. & $\begin{array}{l}\text { Makanan yang dibuat oleh orang } \\
\text { Islam pasti halal }\end{array}$ & $\begin{array}{l}\text { Dari } 64 \text { responden, } \\
25 \% \text { responden } \\
\text { menjawab tidak } \\
\text { pasti halal, } 19 \% \\
\text { ragu-ragu, dan } \\
56 \% \text { responden } \\
\text { yakin pasti halal }\end{array}$ & $\begin{array}{l}\text { Dari } 32 \text { responden, } \\
\text { 19\% menyatakan } \\
\text { tidak pasti halal, } \\
\text { 28\% ragu-ragu, dan } \\
\text { 53\% yakin pasti } \\
\text { halal }\end{array}$ & $\begin{array}{l}\text { Dari } 16 \text { responden, } \\
38 \% \text { menyatakan } \\
\text { tidak pasti halal, } \\
31 \% \text { ragu-ragu, dan } \\
\text { 31\% yakin pasti } \\
\text { halal }\end{array}$ \\
\hline 5. & $\begin{array}{l}\text { Pedagang memiliki pengetahuan } \\
\text { tentang kriteria makanan halal }\end{array}$ & $\begin{array}{l}\text { Dari } 64 \text { responden, } \\
9 \% \text { tidak tahu, } 14 \% \\
\text { ragu-ragu, dan } 77 \% \\
\text { mengetahui kriteria } \\
\text { makanan halal }\end{array}$ & $\begin{array}{l}\text { Dari } 32 \text { responden, } \\
13 \% \text { tidak tahu, } \\
14 \% \text { ragu-ragu, dan } \\
84 \% \text { mengetahui } \\
\text { kriteria makanan } \\
\text { halal }\end{array}$ & $\begin{array}{l}\text { Dari } 16 \text { responden, } \\
6 \% \text { ragu-ragu, dan } \\
94 \% \text { mengetahui } \\
\text { kriteria makanan } \\
\text { halal }\end{array}$ \\
\hline 6. & $\begin{array}{l}\text { Pedagang yakin bahwa bahan } \\
\text { utama (daging, ayam,tepung) dan } \\
\text { bahan tambahan (penyedap rasa, } \\
\text { bahan pewarna) berasal dari } \\
\text { produk halal }\end{array}$ & $\begin{array}{l}\text { Dari } 64 \text { responden, } \\
8 \% \text { menjawab ragu } \\
\text { dan } 92 \% \text { merasa } \\
\text { yakin semua bahan } \\
\text { dagangannya halal } \\
\end{array}$ & $\begin{array}{l}\text { Dari } 32 \text { responden, } \\
6 \% \text { tidak yakin dan } \\
94 \% \text { yakin semua } \\
\text { bahan dagangannya } \\
\text { halal }\end{array}$ & $\begin{array}{l}\text { Dari } 16 \text { responden, } \\
6 \% \text { tidak yakin, } 6 \% \\
\text { ragu-ragu, dan } 88 \% \\
\text { yakin semua bahan } \\
\text { dagangannya halal }\end{array}$ \\
\hline
\end{tabular}




\begin{tabular}{|c|c|c|c|c|}
\hline & $\begin{array}{l}\text { C. Pemahaman tentang } \\
\text { sertifikasi halal }\end{array}$ & & & \\
\hline 7. & $\begin{array}{l}\text { Pengetahuan tentang sertifikasi } \\
\text { halal }\end{array}$ & $\begin{array}{l}\text { Dari } 64 \text { responden, } \\
34 \% \text { menyatakan } \\
\text { tidak tahu } \\
\text { sertifikasi halal, } \\
55 \% \text { tahu dan } 11 \% \\
\text { ragu-ragu }\end{array}$ & $\begin{array}{l}\text { Dari } 32 \text { responden, } \\
13 \% \text { menyatakan } \\
\text { tidak tahu sertifikasi } \\
\text { halal, } 84 \% \text { tahu dan } \\
\text { 3\% ragu-ragu }\end{array}$ & $\begin{array}{l}\text { Dari } 16 \text { responden, } \\
6 \% \text { menyatakan } \\
\text { tidak tahu } \\
\text { sertifikasi halal, } \\
\text { dan } 94 \% \text { tahu } \\
\text { tentang sertifikasi } \\
\text { halal }\end{array}$ \\
\hline 8. & $\begin{array}{l}\text { Perlunya cap/label halal pada } \\
\text { makanan halal }\end{array}$ & $\begin{array}{l}\text { Dari } 64 \text { responden, } \\
69 \% \text { merasa perlu } \\
\text { adanya label halal, } \\
14 \% \text { tidak perlu, } \\
\text { dan sisanya } 17 \% \\
\text { ragu-ragu }\end{array}$ & $\begin{array}{l}\text { Dari } 32 \text { responden, } \\
72 \% \text { merasa perlu } \\
\text { adanya label halal, } \\
16 \% \text { tidak perlu, } \\
\text { dan sisanya } 12 \% \\
\text { ragu-ragu }\end{array}$ & $\begin{array}{l}\text { Dari } 16 \text { responden, } \\
\text { semua responden } \\
\text { menganggap perlu } \\
\text { adanya label halal } \\
\text { pada makanan halal }\end{array}$ \\
\hline \multirow[t]{2}{*}{9.} & $\begin{array}{l}\text { Pemahaman tentang kewajiban } \\
\text { semua produk makanan yang } \\
\text { diperjualbelikan untuk } \\
\text { bersertifikat halal pada } 2019\end{array}$ & $\begin{array}{l}\text { Dari } 64 \text { responden, } \\
77 \% \text { menyatakan } \\
\text { tidak tahu, } 12 \% \\
\text { tahu dan } 11 \% \text { ragu- } \\
\text { ragu }\end{array}$ & $\begin{array}{l}\text { Dari } 32 \text { responden, } \\
53 \% \text { menyatakan } \\
\text { tidak tahu, } 22 \% \\
\text { tahu, dan } 25 \% \text { ragu- } \\
\text { ragu }\end{array}$ & $\begin{array}{l}\text { Dari } 16 \text { responden, } \\
69 \% \text { menyatakan } \\
\text { tidak tahu, } 25 \% \\
\text { tahu, dan } 6 \% \text { ragu- } \\
\text { ragu }\end{array}$ \\
\hline & $\begin{array}{l}\text { D. Upaya untuk memperoleh } \\
\text { sertifikasi halal }\end{array}$ & & & \\
\hline 10. & $\begin{array}{l}\text { Produk makanan yang dijual } \\
\text { sudah bersertifikat halal }\end{array}$ & $\begin{array}{l}\text { Dari } 64 \text { responden, } \\
16 \% \text { produknya } \\
\text { telah bersertifikat } \\
\text { halal dan } 84 \% \\
\text { belum bersertifikat } \\
\text { halal }\end{array}$ & $\begin{array}{l}\text { Dari } 32 \text { responden, } \\
38 \% \text { produk telah } \\
\text { bersertifikat halal, } \\
59 \% \text { belum } \\
\text { bersertifikat halal, } \\
3 \% \text { ragu-ragu }\end{array}$ & $\begin{array}{l}\text { Dari } 16 \text { responden, } \\
75 \% \text { produk telah } \\
\text { bersertifikat halal, } \\
25 \% \text { belum } \\
\text { bersertifikat halal, }\end{array}$ \\
\hline 11. & $\begin{array}{l}\text { Pedagang mengetahui proses } \\
\text { sertifikasi halal }\end{array}$ & $\begin{array}{l}\text { Dari } 64 \text { responden, } \\
67 \% \text { tidak tahu } \\
\text { proses sertifikasi } \\
\text { halal, } 16 \% \text { tahu dan } \\
17 \% \text { ragu-ragu }\end{array}$ & $\begin{array}{l}\text { Dari } 32 \text { responden, } \\
44 \% \text { tidak tahu } \\
\text { proses sertifikasi } \\
\text { halal, } 31 \% \text { tahu, } \\
\text { dan } 25 \% \text { ragu-ragu }\end{array}$ & $\begin{array}{l}\text { Dari } 16 \text { responden, } \\
25 \% \text { tidak tahu } \\
\text { proses sertifikasi } \\
\text { halal, } 75 \% \text { tahu }\end{array}$ \\
\hline \multirow[t]{2}{*}{12.} & $\begin{array}{l}\text { Pedagang memiliki keinginan } \\
\text { untuk mensertifikasi produk } \\
\text { makanan }\end{array}$ & $\begin{array}{l}\text { Dari } 64 \text { responden, } \\
64 \% \text { berkeinginan } \\
\text { untuk } \\
\text { mensertifikasi } \\
\text { produknya, } 17 \% \\
\text { tidak, dan sisanya } \\
19 \% \text { ragu-ragu }\end{array}$ & $\begin{array}{l}\text { Dari } 32 \text { responden, } \\
75 \% \text { berkeinginan } \\
\text { untuk } \\
\text { mensertifikasi } \\
\text { produknya, 22\% } \\
\text { tidak, dan sisanya } \\
\text { 3\% ragu-ragu }\end{array}$ & $\begin{array}{l}\text { Dari } 16 \text { responden, } \\
\text { semua responden } \\
\text { berkeinginan untuk } \\
\text { mensertifikasi } \\
\text { produknya }\end{array}$ \\
\hline & $\begin{array}{l}\text { E. Keterkaitan sertifikat/label } \\
\text { halal dengan penjualan }\end{array}$ & & & \\
\hline 13. & $\begin{array}{l}\text { Pedagang menganggap sertifikat } \\
\text { halal penting dimiliki }\end{array}$ & $\begin{array}{l}\text { Dari } 64 \text { responden, } \\
67 \% \text { menganggap } \\
\text { penting memiliki } \\
\text { sertifikasi halal, } \\
17 \% \text { tidak penting, } \\
\text { dan } 16 \% \text { ragu-ragu }\end{array}$ & $\begin{array}{l}\text { Dari } 32 \text { responden, } \\
84 \% \text { menganggap } \\
\text { penting memiliki } \\
\text { sertifikasi halal, } \\
10 \% \text { tidak penting, } \\
\text { dan } 6 \% \text { ragu-ragu }\end{array}$ & $\begin{array}{l}\text { Dari } 16 \text { responden, } \\
\text { semua responden } \\
\text { menganggap } \\
\text { penting memiliki } \\
\text { sertifikasi halal }\end{array}$ \\
\hline
\end{tabular}




\begin{tabular}{|c|c|c|c|c|}
\hline 14. & $\begin{array}{l}\text { Pedagang merasa yakin dengan } \\
\text { adanya label halal dapat } \\
\text { meningkatkan jumlah penjualan }\end{array}$ & $\begin{array}{l}\text { Dari } 64 \text { responden, } \\
56 \% \text { yakin label } \\
\text { halal dapat } \\
\text { meningkatkan } \\
\text { penjualan, } 17 \% \\
\text { tidak, dan } 27 \% \\
\text { ragu-ragu }\end{array}$ & $\begin{array}{l}\text { Dari } 32 \text { responden, } \\
59 \% \text { yakin label } \\
\text { halal dapat } \\
\text { meningkatkan } \\
\text { penjualan, 3\% } \\
\text { tidak, dan 38\% } \\
\text { ragu-ragu }\end{array}$ & $\begin{array}{l}\text { Dari } 16 \text { responden, } \\
56 \% \text { yakin label } \\
\text { halal dapat } \\
\text { meningkatkan } \\
\text { penjualan, } 0 \% \\
\text { tidak, dan } 44 \% \\
\text { ragu-ragu }\end{array}$ \\
\hline 15. & $\begin{array}{l}\text { Pedagang merasa yakin sertifikasi } \\
\text { halal dapat mempengaruhi minat } \\
\text { pembeli terhadap produk } \\
\text { makanannya }\end{array}$ & $\begin{array}{l}\text { Dari } 64 \text { responden, } \\
53 \% \text { yakin } \\
\text { sertifikasi halal } \\
\text { memengaruhi minat } \\
\text { pembeli, } 28 \% \text { ragu- } \\
\text { ragu dan } 19 \% \\
\text { menyatakan tidak } \\
\text { berpengaruh }\end{array}$ & $\begin{array}{l}\text { Dari } 32 \text { responden, } \\
66 \% \text { yakin } \\
\text { sertifikasi halal } \\
\text { memengaruhi minat } \\
\text { pembeli, dan } 34 \% \\
\text { ragu-ragu. }\end{array}$ & $\begin{array}{l}\text { Dari } 16 \text { responden, } \\
56 \% \text { yakin } \\
\text { sertifikasi halal } \\
\text { memengaruhi minat } \\
\text { pembeli, dan } 44 \% \\
\text { ragu-ragu. }\end{array}$ \\
\hline \multirow[t]{2}{*}{16.} & $\begin{array}{l}\text { Label halal pada produk dapat } \\
\text { meningkatkan keuntungan yang } \\
\text { diperoleh }\end{array}$ & $\begin{array}{l}\text { Dari } 64 \text { responden, } \\
44 \% \text { responden } \\
\text { setuju label halal } \\
\text { pada produk dapat } \\
\text { meningkatkan } \\
\text { keuntungan, } 34 \% \\
\text { ragu-ragu dan } 22 \% \\
\text { tidak }\end{array}$ & $\begin{array}{l}\text { Dari } 32 \text { responden, } \\
69 \% \text { responden } \\
\text { setuju label halal } \\
\text { pada produk dapat } \\
\text { meningkatkan } \\
\text { keuntungan, dan } \\
31 \% \text { ragu-ragu }\end{array}$ & $\begin{array}{l}\text { Dari } 16 \text { responden, } \\
69 \% \text { responden } \\
\text { setuju label halal } \\
\text { pada produk dapat } \\
\text { meningkatkan } \\
\text { keuntungan, 25\% } \\
\text { ragu-ragu dan 6\% } \\
\text { tidak }\end{array}$ \\
\hline & F. Sosialisasi sertifikasi halal & & & \\
\hline 17. & $\begin{array}{l}\text { Pedagang pernah mendapatkan } \\
\text { sosialisasi tentang sertifikasi halal }\end{array}$ & $\begin{array}{l}\text { Dari } 64 \text { responden, } \\
84 \% \text { menyatakan } \\
\text { tidak pernah } \\
\text { mendapatkan } \\
\text { sosialisasi } \\
\text { sertifikasi halal dan } \\
16 \% \text { menyatakan } \\
\text { pernah }\end{array}$ & $\begin{array}{l}\text { Dari } 32 \text { responden, } \\
78 \% \text { menyatakan } \\
\text { tidak pernah } \\
\text { mendapatkan } \\
\text { sosialisasi } \\
\text { sertifikasi halal, dan } \\
22 \% \text { menyatakan } \\
\text { pernah }\end{array}$ & $\begin{array}{l}\text { Dari } 16 \text { responden, } \\
38 \% \text { menyatakan } \\
\text { tidak pernah } \\
\text { mendapatkan } \\
\text { sosialisasi } \\
\text { sertifikasi halal, } \\
\text { dan } 62 \% \\
\text { menyatakan pernah }\end{array}$ \\
\hline
\end{tabular}

Berdasarkan data yang digambarkan dalam tabel di atas menunjukkan beberapa hal, yaitu:

1. Urgensi produk makanan halal

Semua pelaku UMKM di Jatinangor memandang penting terhadap keberadaan produk makanan halal di Jatinangor. Komitmen untuk menghasilkan produk makanan halal ini didasari oleh keyakinan bahwa semua produk makanan yang dikonsumsi orang Islam harus halal, mengingat mayoritas pelanggan produk makanan UMKM di Jatinangor beragama Islam. Atas dasar keyakinan tersebut maka UMKM makanan di Jatinangor berupaya untuk menyajikan makanan halal kepada para konsumennya. Walaupun semua pelaku UMKM di Jatinangor berkeyakinan bahwa semua produk makanan yang dikonsumsi orang Islam harus halal tetapi tidak semua pelaku UMKM memiliki keyakinan yang penuh bahwa produk makanan dan minuman yang mereka jual terjamin kehalalannya. Selain itu, data juga menemukan bahwa ternyata tidak semua pedagang UMKM di Jatinangor memeluk agama Islam. Tentu saja hal ini dapat menimbulkan 
kekhawatiran tambahan bagi konsumen tentang kehalalan makanan yang dijual UMKM di Jatinangor. Dengan demikian, resiko untuk mengonsumsi makanan tidak halal di Jatinangor saat ini menjadi semakin besar.

2. Pemahaman tentang cara produksi makanan halal

Terkait dengan adanya keyakinan masyarakat umum bahwa makanan yang dibuat oleh orang Islam pasti halal. Data menunjukkan bahwa semakin besar skala usaha UMKM keyakinan terhadap kehalalan produk makanan yang dibuat oleh Muslim justru semakin menurun. Hal ini disebabkan oleh besar kecilnya kontrol pelaku usaha terhadap proses produksi makanan yang dijual. Para pelaku usaha mikro cenderung memiliki kontrol penuh terhadap proses produksi dan bahan makanan yang digunakan sehingga keyakinan terhadap kehalalan makanan yang dihasilkan menjadi tinggi. Sementara pelaku usaha kecil bahkan menengah relatif memiliki kontrol yang lebih sedikit terhadap proses produksi dan bahan makanan yang mereka jual sehingga hal tersebut turut mengurangi keyakinan mereka terhadap kehalalan produk yang mereka hasilkan. Keyakinan UMKM terhadap produk makanan yang mereka hasilkan memenuhi unsur halal hanya bersandarkan kepada klaim sepihak. Klaim tersebut berangkat dari asumsi bahwa makanan yang diproduksi oleh seorang Muslim pasti halal, sementara para pedagang UMKM ini mayoritas beragama Islam. Selain itu, kehalalan suatu makanan hanya didasarkan pada kriteria yang sangat sederhana yaitu ada tidaknya kandungan babi dan tidak berasal dari bangkai. Tetapi sebagian kecil diantara para pedagang UMKM juga memiliki ketidakyakinan terhadap kehalalan produk makanan yang mereka hasilkan terutama untuk produk makanan yang menggunakan bahan tambahan. Bahan tambahan atau bahan penolong dalam beberapa produk makanan digunakan bersama-sama dengan bahan baku utama untuk membuat suatu olahan produk makanan yang mereka jual. Bahan baku atau bahan penolong ini merupakan bahan yang tidak diketahui kehalalannya secara pasti. Tentu hal tersebut berada di luar kuasa mereka yang hanya mengandalkan prasangka baik saja tentang kehalalannya. Padahal agar suatu produk makanan disebut sebagai makanan halal maka semua produknya baik bahan utama, tambahan maupun penolong harus terjamin kehalalannya.

3. Pemahaman tentang sertifikasi halal

Ironinya, walaupun hampir semua pelaku UMKM di Jatinangor memeluk agama Islam, ternyata masih ada sebagian pelaku UMKM yang tidak mengetahui tentang sertifikasi halal. Sebagian pelaku UMKM lainnya di Jatinangor telah mengetahui atau setidaknya 
mendengar tentang sertifikasi halal. Bahkan mereka berpendapat tentang pentingnya label atau cap halal pada semua produk makanan halal. Hal ini dimaksudkan untuk memperjelas status kehalalan makanan tersebut sekaligus memberikan informasi dan menambah keyakinan dari para konsumennya. Akan tetapi, mayoritas pedagang tidak mengetahui tentang adanya kewajiban sertifikasi halal bagi semua produk yang akan mulai berlaku pada tahun 2019 seiring dengan pemberlakuan UU No. 33 Tahun 2014 tentang Jaminan Produk Halal. Dengan demikian, terdapat dua masalah utama pelaku UMKM terkait sertifikasi halal yaitu masih adanya pelaku UMKM yang belum mengetahui tentang sertifikasi halal dan masalah lainnya adalah mayoritas pelaku UMKM di Jatinangor belum mengetahui pemberlakuan kewajiban sertifikasi halal terhadap semua produk yang diperjualbelikan di Indonesia pada tahun 2019. Padahal tahun 2019 hanya tinggal beberapa bulan lagi. Artinya perlu adanya upaya yang sungguh-sungguh untuk mengatasi dua masalah tersebut mengingat waktu yang tersedia sangat terbatas.

4. Upaya untuk memperoleh sertifikasi halal

Survei menunjukkan bahwa semakin tinggi level usaha, maka semakin besar jumlah pelaku usaha yang telah memiliki sertifikat halal. Pelaku usaha mikro yang telah memiliki sertifikat halal jumlahnya lebih sedikit dibandingkan dengan pelaku usaha kecil, begitu pula seterusnya pelaku usaha kecil yang telah memiliki sertifikat jumlahnya lebih kecil dibandingkan pelaku usaha menengah yang telah memiliki sertifikat halal. Kondisi ini sangat memperihatinkan mengingat jumlah pelaku usaha yang masuk kategori mikro dan kecil jumlahnya lebih banyak daripada pelaku usaha menengah. Artinya jumlah pelaku usaha UMKM yang telah memperoleh sertifikat halal jumlahnya lebih sedikit dibandingkan pelaku usaha yang belum memiliki sertifikat halal. Konsekuensinya adalah jumlah produk makanan UMKM di Jatinangor yang terjamin kehalalannya lebih sedikit dibandingkan dengan jumlah produk makanan yang tidak terjamin kehalalannya. Selain itu, walaupun pedagang UMKM di Jatinangor memiliki komitmen dan keinginan untuk menghasilkan produk makanan halal serta memiliki pengetahuan tentang sertifikasi halal, pada realitanya mayoritas pelaku UMKM di Jatinangor belum memiliki sertifikat halal yang dikeluarkan oleh lembaga berwenang yaitu LPPOM MUI. Adapun yang menjadi hambatannya adalah para pelaku UMKM di Jatinangor tidak memiliki pengetahuan yang cukup mengenai tata cara dan proses pendaftaran sertifikasi halal dari LPPOM MUI. Selain itu, besarnya aspek biaya 
yang harus dikeluarkan oleh para pelaku UMKM dalam proses pengajuan sertifikasi halal juga menjadi hambatan tersendiri.

5. Keterkaitan sertifikat/label halal dengan penjualan

Secara umum para pelaku UMKM makanan di Jatinangor mengetahui bahwa kepemilikan sertifikat halal atas produk yang mereka hasilkan akan meningkatkan minat beli masyarakat terhadap produk yang mereka tawarkan. Hal ini tentu berkorelasi dengan peningkatan jumlah penjualan produk dan pada akhirnya juga berpengaruh terhadap peningkatan keuntungan yang akan mereka dapatkan. Oleh karena itu, sertifikasi halal dapat meningkatkan mutu dan prestise suatu produk sehingga memiliki nilai tambah di mata para pelanggannya. Menariknya ada keyakinan yang lebih kecil dari level usaha mikro dibandingkan dengan usaha kecil dan menengah tentang potensi label halal pada produk dapat meningkatkan keuntungan yang diperoleh. Ketidakyakinan potensi laba yang akan diperoleh walaupun sudah berlabel halal disebabkan karena pedagang mikro di Jatinangor tidak merasa yakin bahwa sertifikasi halal dapat mempengaruhi minat pembeli terhadap produk makanannya. Oleh karena itu, wajar sekali jika masih ada anggapan di kalangan pedagang mikro dan kecil di Jatinangor bahwa sertifikat halal tidak penting dimiliki oleh mereka.

6. Sosialisasi sertifikasi halal

Secara umum pedagang UMKM di Jatinangor belum pernah memperoleh sosialisasi tentang sertifikasi halal terutama untuk kategori pedagang mikro dan kecil. Jika dilihat dari kecenderungannya, semakin besar skala usaha maka semakin banyak pelaku usaha yang telah memperoleh sosialisasi sertifikasi halal, begitu pula sebaliknya. Artinya sosialisasi sertifikasi halal yang telah dilakukan oleh pemerintah dan lembaga-lembaga terkait lainnya hanya menyasar UMKM dengan kategori menengah dan cenderung kurang memperhatikan pemberiaan sosialisasi sertifikasi halal terhadap pelaku usaha mikro dan kecil di Jatinangor. Padahal jika dibandingkan secara kuantitatif, jumlah UMKM kategori mikro dan kecil jumlah lebih besar dibandingkan dengan UMKM kategori menengah.

Dalam penelitian ini dilakukan beberapa uji statistik. Uji multikolinearitas memperlihatkan tidak terdapat masalah multikolinearitas dalam model ini. Begitu pula dengan uji heteroskedastisitas juga menggambarkan tidak terdapat masalah heteroskedastisitas dalam riset ini. Selanjutnya, uji koefisien determinasi mencerminkan R-Squared dalam dua hasil 
regresi bernilai 0,6044 yang berarti bahwa variabel yang ada pada model hanya mampu menjelaskan kejadian sebesar 60,44\%, sedangkan sisanya 39,56\% dijelaskan oleh variabel lain di luar model.

\section{Gambar 3}

\section{Hasil Regresi Sederhana}

\begin{tabular}{|c|c|c|c|c|c|c|c|c|}
\hline Source & ss & & df & MS & \multirow{2}{*}{\multicolumn{2}{|c|}{$\begin{array}{l}\text { Number of obs } \\
F(1,1) \\
\text { Prob > F }\end{array}$}} & $=$ & 3 \\
\hline Model & 5.11393446 & & 1 & 5.11393446 & & & $=$ & 0.4330 \\
\hline Residual & 3.34688876 & & 1 & 3.34688876 & \multirow{2}{*}{\multicolumn{2}{|c|}{$\begin{array}{l}\text { R-squared } \\
\text { Adj R-squared } \\
\text { Root MSE }\end{array}$}} & $=$ & 0.6044 \\
\hline Total & 8.46082322 & & 2 & 4.23041161 & & & $=$ & 1.8295 \\
\hline pemahaman & Coef. & Std. & Err. & $t$ & $P>|t|$ & {$[95 \% \mathrm{Co}$} & onf. & Interval] \\
\hline sosialisasi & 3.415473 & 2.763 & 3083 & 1.24 & 0.433 & -31.6928 & & 38.52377 \\
\hline _cons & 30.79549 & 4.651 & 1288 & 6.62 & 0.095 & -28.3047 & & 89.89571 \\
\hline
\end{tabular}

Sumber: Laporan KKNM-PPMD Integratif Unpad, 2018

Gambar di atas menjelaskan bahwa setiap terjadinya sosialisasi maka pemahaman sertifikasi halal pada UMKM di Jatinangor akan meningkat sebesar 3,415473 satuan namun tidak berpengaruh secara signifikan. Hasil perhitungan juga memperlihatkan bahwa semakin besar skala usaha maka pemahaman akan sertifikasi halal akan semakin besar. Hal tersebut tercermin dari hasil skor usaha mikro memiliki nilai pemahaman sebesar 34,095, sementara itu usaha kecil mendapatkan skor 37,03 dan usaha menengah memiliki skor 38,059. Skor sosialisasi pun memiliki nilai yang lebih besar seiring naiknya skala usaha. Selanjutnya ketika dilakukan kegiatan sosialisasi sertifikasi halal terhadap usaha mikro maka diperoleh skor sosialisasi bernilai 1,317 sementara usaha kecil mendapatkan skor 1,424 dan usaha menengah mempunyai skor sosialisasi 2,176. Hal ini menggambarkan bahwa semakin besar skala usaha maka kegiatan sosialisasi sertifikasi halal akan semakin efektif.

\section{SIMPULAN}

Pemahaman para pelaku bisnis atau UMKM makanan dan minuman di Jatinangor masih tergolong rendah. Hal itu ditunjukan dengan jumlah mayoritas produk makanan yang dihasilkan oleh UMKM di Jatinangor masih belum teruji kehalalannya secara resmi mengingat hanya sebagian kecil produk makanan di Jatinangor yang telah memiliki sertifikat halal dari LPPOM MUI. Walaupun banyak pelaku UMKM di Jatinangor yang mengaku bahwa produk makanan atau minuman yang diperdagangkannya adalah halal akan tetapi klaim tersebut belum bisa dibuktikan secara valid. Kehalalan produk makanan yang dihasilkan oleh pedagang UMKM di Jatinangor baru sebatas klaim sepihak dari para pedagangnya, belum memperoleh jaminan halal 
secara resmi dari lembaga yang kompeten dan berwenang yaitu LPPOM MUI. Selain itu, dasar klaim halal yang dilakukan oleh UMKM disandarkan pada kriteria halal yang sangat umum dan sederhana yaitu hanya sebatas diproduksi oleh orang Islam, tidak mengandung babi, dan bukan berasal dari bangkai. Padahal untuk dapat menjamin kehalalan suatu produk makanan, selain bahan baku harus menggunakan bahan baku halal juga harus dipenuhi ketentuan tentang kehalalan bahan baku tambahan, proses pembuatan, pengemasan hingga distribusi produk.Oleh karenanya kepastian kehalalan produk hanya bisa diperoleh melalui lembaga pemeriksa halal yang berwenang yaitu LPPOM MUI.

Rendahnya pemahaman pelaku UMKM tentang sertifikasi halal disebabkan karena masih minimnya kegiatan sosialisasi sertifikasi halal baik yang dilakukan oleh lembaga pemerintah, lembaga keagamaan ataupun komponen masyarakat lainnya. Dengan demikian, perlu adanya upaya kegiatan sosialisasi sertifikasi halal yang masif, kontinyu dan terarah kepada para pelaku UMKM di Jatinangor khususnya pelaku UMKM kategori mikro dan kecil. Selain itu, perlu juga adanya bantuan dana khusus atau hibah dari pemerintah, donatur, dan pihak lainnya kepada para pelaku UMKM kategori mikro dan kecil di Jatinangor agar dapat segera mengurus proses pendaftaran sertifikasi halal yang selama ini menjadi salah satu masalah utama bagi mereka.

\section{UCAPAN TERIMAKASIH}

Terima kasih yang setinggi-tingginya kami ucapkan kepada institusi kami, Universitas Padjadjaran, yang telah membiayai dan mendukung kegiatan KKNM-PPMD dan Hibah Internal Unpad 2018. Ucapan terima kasih juga kami sampaikan kepada para mahasiswa yang tergabung dalam program KKNM-PPMD Integratif 2018 di Kecamatan Jatinangor atas kontribusinya dalam riset ini serta kepada para pelaku UMKM di Jatinangor yang telah bersedia untuk memberikan informasi dan data riset yang sangat berharga.

\section{DAFTAR PUSTAKA}

Abdullah, I. 2017. Mandatory Sertifikasi Halal dan Keberlansungan Dunia Usaha. Tersedia online pada https://republika.co.id/berita/jurnalisme-warga/wacana/17/12/28/p1npq4396mandatory-sertifikasi-halal-dan-keberlansungan-dunia-usaha, diakses 9 Oktober 2018.

Akim, Konety, dan Purnama, C. 2018. Laporan KKNM-PPMD Integratif: Sosialisasi Sertifikasi Halal Terhadap UMKM di Jatinangor. Sumedang.

BPS Kabupaten Sumedang. 2018. Kabupaten Sumedang dalam Angka. Sumedang. Tersedian online pada 
https://sumedangkab.bps.go.id/publication/2018/08/16/a8d2e4cde56be554cc4765a2/kab upaten-sumedang-dalam-angka-2018.html, diakses 20 Januari 2019.

Dinas Komunikasi dan Informatika Persandian dan Statistik Kabupaten Sumedang. 2017. Indikator Ekonomi Makro Kabupaten Sumedang Tahun 2012-2016. Sumedang. Tersedia online pada https://mcapsumedang.files.wordpress.com/2018/01/pdrb-kecamatan2017.pdf, diakses pada 8 Januari 2019

Huda, N. 2012. Pemahaman Produsen Makanan tentang Sertifikasi Halal (Studi Kasus di Surakarta). Ishraqi, 10(1): 1-13.

LPPOM MUI. 2008. Panduan Umum Sistem Jaminan Halal LPPOM - MUI. Jakarta. Tersedia online pada http://www.halalmui.org/images/stories/pdf/sjh-indonesia.pdf, diakses 9 Oktober 2018.

Nasar, M. F. 2017. Negara dan Sertifikasi Halal Indonesia Negara dan Sertifikasi Halal Indonesia. Tersedia online pada https://kemenag.go.id/berita/read/505898/negara-dansertifikasi-halal-indonesia, diakses pada 11 Desember 2018.

Purnama, C. 2015. Sertifikasi Halal dalam Produk UMKM. Tersedia online pada http://radarsemarang.com/2015/12/15/sertifikasi-halal-dalam-produk-umkm/, diakses pada 7 Oktober 2018.

Purnomo, D. 2011. Strategi Pengembangan Agroindustri Halal dalam Mengantisipasi Bisnis Halal Global. Disertasi. Bogor: Institut Pertanian Bogor.

Salehudin, I. 2010. Halal Literacy: A Concept Exploration and Measurement Validation. Asean Marketing Journal, 2(1): 1-12.

Undang-Undang No. 33 Tahun 2014 tentang Jaminan Produk Halal 